\title{
VOCATIONAL SCHOOLS AND ARTS \& CRAFTS INFLUENCES IN TRANSYLVANIA FROM THE GREAT EXHIBITION TO BAUHAUS*
}

\author{
MIKLÓS SZÉKELY**
}

\begin{abstract}
The paper discusses the approximately 100-year presence and transformation of the approach and mentality of arts and craft movements which emerged in the mid-19th century from the aspect of industrial education workshops in Transylvania. In late 19th-century Hungary, the approach of artistic innovation, spread with the help of William Morris's and Walter Crane's works, is perhaps most immediately seen in the creative workshops that approached the relationship between aesthetics and technology rather differently. It appeared in the works of the British Arts \& Crafts movement and also in the curriculum of late 19th-century Hungarian vocational schools and institutions of vocational education, as well as in the methodology of art reform movements that sprung up after World War I, the most familiar example of which was the Bauhaus. The guidelines for workshop-based education and training, the implementation of technical innovations and new artistic trends into the education, an emphasis on the students' individual skills, facilitating the individual's creativity and imagination, the primary role of architecture, the adaptation of basic building principles of modern homes, strong personal relationship and cooperation between teachers and students were the bases of the educational reform that started in the 1840s and continued for a century. The curriculum of industrial vocational schools in Hungary included the development of drawing, modelling and form-creation skills, with the help of which many of those who graduated from these institutions, made a great impact on avantgarde and modernism between the two world wars.
\end{abstract}

Keywords: vocational education, industrial education, applied arts, design, Arts and Crafts movement, Bauhaus

\footnotetext{
* This paper was supported by the János Bolyai Scholarship of the Hungarian Academy of Sciences and the ÚNKP-19-4-KRE-5 New National Excellence Program of the Ministry of Human Capacities.

${ }^{* *}$ Dr. Miklós Székely research fellow, deputy director Institute of Art History, Research Centre for the Humanities, ELKH, Budapest, Email szekely.miklos@btk.mta.hu
} 
REZUMAT. Școli profesionale și influențe ale Arts\&Crafts în Transilvania de la Expoziția Universală la Bauhaus. Studiul dorește să prezinte prezența și evoluția concepției și modului de gândire a diverselor curente ale mișcărilor de reformare ale artelor aplicate prin prisma activității atelierelor școlilor profesionale din Transilvania. La sfârșitul secolului al XIX-lea noua concepție a reformării artelor aplicate este răspândită în Ungaria în primul rând prin operele lui William Morris și Walter Crane, și se reflectă într-o serie de ateliere de creație care interpretează într-un mod diferit relația dintre estetică și tehnologie. Această nouă concepție apare atât în operele mișcării britanice Arts \& Crafts, cât și în programele școlare ale instituțiilor de învățământ ale artelor aplicate și industriale, dar și în metodele unor mișcări reformatoare artistice de după primul război mondial, al căror cel mai cunoscut exemplu este Bauhaus. Noile curente europene ajung în Transilvania din două direcții fundamental distincte, comenzile comunităților locale fiind realizate de artizani formați în școli de stat. Comenzile comunelor și orașelor au creat lucrări spectaculoase și reprezentative, executate în spiritul mișcărilor reformatoare ale artelor aplicate de la cumpăna secolelor al XIX-lea și XX, care reprezentau puterea, bogăția și deschiderea față de modernitate a acestor comunități locale. Printre exemplele cele mai cunoscute merită amintită clădirea Palatului Culturii din Târgu Mureș, un adevărat Gesamtkunstwerk al epocii, decorațiile interioare ale bisericii Inima Sfântă a lui Isus din Ditrău sau Muzeul Național Secuiesc din Sfântu Gheorghe, care se remarcă prin modernizarea tradițiilor arhitecturale vernaculare. Formarea proiectanților și executanților acestor mari realizări ale epocii, modelele folosite pe parcursul formării lor, pregătirea și concepția profesorilor și organizarea atelierelor urmăreau practica modernă europeană a epocii. În transmiterea acestor cunoștințe un rol primordial îi revenea și statului: în anii 1890 au fost organizate într-un sistem unitar și au fost înzestrate cu cele mai moderne dotări școlile de specialitate, printre care găsim atât instituții de învățământ fondate la inițiative locale, cât și școli înființate de administrația centrală. Modernizarea accelerată a adus și în Transilvania o nouă calitate arhitecturală și vizuală: pe parcursul unei generații tradițiile vii ale breslelor, care persistă încă și în anii 1870, au fost înlocuite de o largă folosire a celor mai noi materiale, tehnologii și modele. Modernizarea radicală este ilustrată de cazul orașului Târgu Mureș: în timp ce în anii 1890 la edificarea Muzeului Industrial Secuiesc, construit după proiectele lui István Kiss, meșterii locali au putut contribui aproape numai prin zidari, o serie de clădiri construite în anii 1910 la comanda administrației locale, a unor asociații și societăți sau la comenzi private exemplifică deja efortul unor proiectanți și executanți locali. Pe lângă tema formării artizanilor arhitecturii și al artelor aplicate, foarte puțin cercetată în literatura de specialitate, studiul prezintă și manifestarea procesului de proiectare bazat și pe realizarea talentului personal, a importanței unor considerente sociale, a relației directe dintre profesor și elevi, a principiului care accentua importanța muncii colective, caracteristice în aceste ateliere de creație a unor școli cu concepții aparent diferite.

Cuvinte cheie: învățământ profesional, învățământ industrial, arte aplicate, design, mișcarea Arts and Crafts, Bauhaus 
REZÜMÉ: Ipari szakoktatás és Arts and Crafts hatások Erdélyben a londoni világkiállítástól Bauhausig. A tanulmány a 19. század közepén induló iparművészeti mozgalmak szemléletének, gondolkodásmódjának mintegy száz éves jelenlétét, átalakulását mutatja be az erdélyi ipari szakoktatás múhelyein keresztül. A 19. század végi Magyarországon elsősorban William Morris és Walter Crane alkotásain keresztül elterjedt művészeti újítás szemlélete az esztétika és technológia viszonyát igen eltérően megközelítő alkotói múhelyekben mutatható ki. Megjelent ugyanúgy a brit Arts \& Crafts mozgalom alkotásaiban, mint a 19. század végi magyarországi iparmúvészeti és ipari szakoktatási intézmények tanterveiben, vagy az első világháború után szárba szökkent olyan múvészeti reformmozgalmak módszertanában is, amelyek legismertebb példája a Bauhaus. Erdélybe két alapvetően eltérő irányból érkeztek meg az új európai áramlatok, a helyi közösségek megrendeléseit állami iskolákban képzett iparosok teljesítették. A községi városi megrendelések a századfordulós iparművészeti mozgalmak szellemiségében született látványos, reprezentatív alkotásokat hoztak létre, a helyi közösségek erejét, gazdagságát és modernizmus iránti nyitottságát jelezték. Jórészt Budapesten működő építészek alkotásai közé tartozik a marosvásárhelyi Kultúrpalota Gesamtkunstwerk épülete, a gyergyóditrói Jézus Szent Szíve templom belső díszítése, vagy a vernakuláris építészeti hagyományt modernizáló sepsiszentgyörgyi Székely Nemzeti Múzeum. A nagyszabású megrendelések tervezőinek és kivitelezőinek képzése, az oktatásuk során felhasznált minták, a tanárok képzettsége és szemlélete, a múhelyek szervezése a korszak modern európai gyakorlatát követte. Ennek a tudásnak az átadásában a magyar államnak alapvető szerep jutott: az 1890-es években egységes rendszerbe szervezték és a modern eszközökkel szerelték fel az iskolákat, amelyek között találunk helyi kezdeményezésre létrejött iskolákat és állami alapításúakat egyaránt. A rendkívül gyors modernizálás új építészeti és vizuális minőséget hozott létre Erdélyben: az 1870-es évek még élő céhes hagyományait egy emberöltő alatt a legújabb anyagok, technológiák és minták széles körű használata váltotta fel. A radikális modernizálódást Marosvásárhely esete illusztrálja: míg az 1890-es években a Kiss István tervei szerint felépült Székelyföldi Iparmúzeum felépítéséhez a helyi iparosság jóformán csak kőmúveseivel tudott hozzájárulni, addig az 1910-es évek testületi, városi és magán megrendelésre tervezett épületeinek sora példázza helyi tervezők és iparosok kivitelezői munkáját. Az építészet és iparmúvészet napszámosainak eddig kevéssé kutatott oktatása mellett a tanulmány az egyéniséget kibontakoztató tervezés, a szociális szempontok érvényesülésének, a közvetlen tanár-diák viszonynak, a közös munkát a középpontba állító múködés elveinek a megnyilvánulását mutatja be ezekben az egymástól látszólag eltérő szemléletű iskolai alkotói műhelyekben.

Kulcsszavak: szakoktatás, iparoktatás, iparmúvészet, dizájn, Arts and Crafts mozgalom, Bauhaus 


\section{Introduction}

The paper discusses the approximately 100-year presence and transformation of the approach and mentality of arts and craft movements which emerged in the mid-19 $9^{\text {th }}$ century from the aspect of industrial education workshops in Transylvania. In late $19^{\text {th }}$-century Hungary, the approach of artistic innovation, spread with the help of William Morris's and Walter Crane's works, is perhaps most immediately seen in the creative workshops that approached the relationship between aesthetics and technology rather differently. It appeared in the works of the British Arts \& Crafts movement and also in the curriculum of late $19^{\text {th }}$-century Hungarian vocational schools and institutions of vocational education, as well as in the methodology of art reform movements that sprung up after World War I, the most familiar example of which was the Bauhaus.

This paper examines the effects of vocational education in Hungary and endeavors to offer new interpretative perspectives on the whole of this education as an institution. With one exception, the examples are tied to the school system in Transylvania. The reason for this is that the mechanisms of industrial and urban development in Transylvania, which were more intensive than comparable mechanism in the rest of Hungary, offer an opportunity for the study of the complete spectrum of applied arts phenomena at the turn of the century. The new European trends arrived in Transylvania from two fundamentally different directions, and orders by the local communities were filled by craftsmen educated in state schools. The architectural commissions of major symbolic importance that were given by the state were located for the most part in Budapest, and they thus essentially avoided Transylvania. In the process of creating national collections, Transylvania was of interest to the experts who worked at the museums in the capital primarily from the perspective of its items of material folk culture. Orders by communities and towns thus led to spectacular and symbolically important works created in the spirit of turn-of-the-century arts and crafts movements and signaling the communities' power, wealth, and openness to modernism. Some examples of works by architects active predominantly in Budapest include the building of Gesamunktwerk, a palace of culture in Târgu Mureș, the interior decoration of the Church of the Sacred Heart of Jesus in Ditrău, or the Szekler National Museum in Sfântu Gheorghe, with its modernization of vernacular architectural traditions. The education of the designers and constructors of these large-scale orders, the models used throughout their training, the qualification and approach of their teachers, and the organization of the workshops all followed the modern European practices of the era. The Hungarian state had a pivotal role in transfering this knowledge: in the 1890 s schools - both local initiative and state-founded - were organized 
under a uniform system and equipped with modern tools. This extremely rapid modernization brought about a new architectural and visual quality in Transylvania: within a generation the traditions of guilds still present in the 1870 s were replaced by an extensive use of the latest materials, technologies, and models. Radical modernization is best illustrated by the case of Târgu Mureș: while during the construction of the Szekler museum of industry, built in the 1890s based on István Kiss's plans, local craftsmen were represented by stonemasons alone, a great many buildings designed in the 1910 s to communal, municipal, or private order exemplify the work of local designers and artisans as constructors.

In addition to considering the education of laborers in architecture and arts and crafts - a hitherto little researched field - the present paper also discusses manifestations of the prevalence of social considerations, the relationships between teachers and students, and the principles of operation focusing on collective work, which were present in these workshops in spite of the fact that they adopted seemingly dissimilar approaches.

\section{Emigration, teaching methodology}

On 1 May 1851, the opening day of the Great Exhibition, John Ruskin was in his room, working on the preface to the second volume of his seminal work, The Stones of Venice. The book posited that art was a reflection of the condition of human society, so there was a direct connection between capitalist industrial society and industrial production of low artistic quality. Ruskin's was the first criticism of the production logic of the 1840s, with its industrial focus, and it laid the groundwork for the basic principles of the guidelines concerning teaching methodology and collection used by vocational and arts and crafts schools.

The two middle decades if the $19^{\text {th }}$ century were a period of fundamental reform in European societies and economies. Processes which sometimes reinforced and sometimes worked against each other led to the emergence of the ideas that determined the system of vocational education in Hungary in the 1890s. With regards to architecture, and building on the scientific world view of the $19^{\text {th }}$ century, Gottfried Semper and, later, John Ruskin offered a formula to understand the world, giving art a distinguished place in their interpretation. The tension between development based on innovation and the need to continue traditions characteristically defined the oeuvre of the two thinkers. This duality was the central problematics of the consecutive educational reforms from the foundation of the South Kensington Museum until the time of the Bauhaus movement. 
Establishing the system of vocational and arts and crafts education, as well as of gathering collections required experts and a continual flow of reform ideas. The reforming of vocational education and arts and crafts in Britain was influenced by significant German impulses, which, in the 1830s and 1840s was owing much to a general social interest in German culture, as well as to the teaching methodology and organization of vocational education. Besides the aforementioned two theoreticians, Queen Victoria's husband, Prince Albert of Saxe-Coburg and Gotha's upbringing and attitude signaled the openness of the highest stratum of society, as exemplified by the school operated by the Science and Art Department at the South Kensington Museum. ${ }^{1}$ The German influence detectable in English reform movements also had textual implications: the German conceptual matrix of arts and crafts, applied art, art drawing, and arts and industry [...] proved to be more powerful than theoretical discourse in English building on the terminology of Innenausstattung (interior design) and Decoration (decoration). ${ }^{2}$ The German influence is also visible in the acceptance of the functionalist approach of Rundbogenstil, applied during the building of the South Kensington Museum, or in the concept and first plans of the cultural district called Albertopolis. Both were commissioned by Prince Albert in the first half of 1855 to be designed by Gottfried Semper, who was still staying in London back then. ${ }^{3}$

The 1840 s and 1850 s were a time not only of economic restructuring but also of political revolutions, and social changes usually went hand in hand with a quick transformation of the methodology and content of education. Besides the representatives of the political movements, the revolutions of the year 1848 also involved the most significant theoreticians of reform in arts and crafts. In fact, the fate of the two often intertwined. In Dresden, Gottfried Semper fought on the barricades of the German Revolution of 1848-1849 for a new civil world he thought to be ideal, and after its fall he fled to London as a political refugee. Karl Marx - also arriving in London in 1849 - penned down his thoughts and argued for the pivotal role the transformation of English industry in the 1840s played in the development of capitalist civil society. In 1850, the beginning of Gottfried Semper's exile in London, the British Empire was feverishly organizing the Great

\footnotetext{
1 Julius Bryant, „Albertopolis”: the German Sources of the Victoria and Albert Museum, in Art and design for all: The Victoria and Albert Museum, Exhibition catalogue, London, V \& A Publishing, 2011, p. 25-40. and Susan Owens, Straight lines are a national want': South Kensington and Art Education Reform, in Art and design for all: op. cit., p. 75-82.

2 Julius Bryant, „Albertopolis”, op., cit., p. 25-40.

3 Christopher Marsden: „Une espèce de monument socialiste moderne: Architecture for the South Kensington Museum", in Art and design for all: op. cit., p. 83-90.
} 
Exhibition of the Works of Industry of All Nations, to be opened in the following year - the title of the event itself indicated the possibility of total reform. In 1852, one year after participating in the building of the Great Exhibition, Semper published his Wissenschaft, Industrie und Kunst: Vorschläge zur Angregung nationalen Kunstgefühles bei dem Schlusse der Londoner Industrie-Austellung, in which he called the German readers' attention to the need for reforming the taste of the public and to the importance of exhibitions, practical workshop training, and museums specialized in industry/arts and crafts, all examples of good planning. On several occasions, the German architect discussed his ideas in German with Prince Albert, whose vision of museal education, beyond organizing the Great Exhibition, included a museum collection that would speak to each strata of society, be of an educational nature, and generate discussion.

Besides the German influence, French art education also left its mark on English reform movements, mainly due to events connected to European high politics. The Franco-Prussian War of 1870-1871 forced several French artists to leave their homeland, including drawing artist Alphonse Legros and sculptor Jules Dalou, who were commissioned to teach copper etching and modelling at the South Kensington Museum in 1875. Their activity fit in well with the process of reorganizing and restructuring education at South Kensington, prioritizing artistic approaches. Shortly, however, the emphasis shifted again, as in 1884 education at the college was criticized for the predominance of artistic considerations and the lack of a technical and knowledge of materials approach to creating objects. There are a number of examples for delineating designer skills from art education in Hungarian vocational education as well. With regards to stone carving, the Czech Vencel (Václav) Knop, teacher of modelling at the school of Stone Carving and Stone Grinding in Zlatna, distinguished between ornamentation acquired by modelling and an artistic approach for education in vocational schools; he claimed that "simple ornamentation [was] the line between stone carving and sculpture; the two, like siblings, [met] right there." ${ }^{4}$ In accordance with the principle first formulated in Victorian England, the subjects of technology and the knowledge of materials, as well as modelling skills in vocational and arts and crafts education had to be developed with due regard to aspects of industrial production. John Ruskin, another significant author on art in the period, believed that the then prevalent attitude to creating objects, characterized by a lack considerations for

4 Miklós Székely, Cioplirea pietrei şi modalităţi de folosire a ipsosului în vechea Şcoală de Stat de Arte şi Meserii pentru Cioplirea şi Şlefuirea Pietrei din Zlatna între anii 1894-1918, Storia Urbana, XXV, 2017, p. 235-260. and Miklós Székely, Az egykori Zalatnai Köfaragó és Köcsiszoló Ipariskola gipszgyüjteménye, „Ars Hungarica”, 42, 2016, p. 174. 
design and artistic qualities, was the result of the separation of the designer's and the manufacturer's role and skills. It was Walter Crane, director of the South Kensington Museum, who could show something new in terms of reconsidering the borderline between a designer's and an artistic attitude, and governing the relationship of the two, in the last years of the $19^{\text {th }}$ century. Crane firmly rejected any differentiation between fine arts and arts and crafts; he established a balance between the skills of the designer of objects, based on technical knowledge and the knowledge of materials, and the transmission of an artistic attitude. ${ }^{5}$ [Fig. 1] Taking the adaptation of medieval crafts as the starting point, the balance of an artistic and a designer's approach continued to be characteristic of the education of designers of objects in vocational schools in Britain up until the first decades of the $20^{\text {th }}$ century. In contrast, German-dominated vocational education in the continent involved the strengthening of the skills of designers of objects in terms of technical knowledge and the knowledge of materials, and was characterized by a disregard for artistic considerations. The appearance of the Bauhaus was a new chapter in the process of the industrial creation of objects by harmonizing artisan techniques, the manufacturer's creativity, and industrial mass production. Lydia Driesch-Foucar started visiting the pottery workshop of the Bauhaus at the turn of 1919 and 1920. By then, she had already known the German system of vocational education well: besides completing her studies at the arts and crafts school of Dusseldorf (Kunstgewerbeschule) she also studied at a vocational school of pottery; then, through the arts and crafts school of Munich, she worked freelance at the workshop of Hutschenreuther pottery factory in Selb. Looking back on those years and the ones spent at the Bauhaus, she summarized the issue of education in the era the following way: "The disaster at the time was that the technical schools placed little value on good artistic design, while in the "arts and crafts" schools, by contract technical and craft ability were completely neglected." ${ }^{6}$ Driesch-Foucar's observations are confirmed by the recollections of Johannes Itten, the instigator and legendary teacher of the famous preparatory course, who described the early years of Bauhaus as the first period of the regular and profound teaching of artistic/designer and technical/industrial considerations. The

5 Susan Owens, 'Straight lines are a national want' op. cit., p. 67. (Crane was head of Royal College of Art between 1898 and 1899. The college was founded as part of the museum in 1896 with the aim of providing arts and crafts education and implemented several new technologies in its educational programme.)

6 Lydia Driesch-Foucar, Memories of the Beginnings of the Dornburg Pottery Workshop of the State Bauhaus in Weimar, in Magdalena Droste-Boris Friedewald (eds.) Our Bauhaus. Memories of Bauhaus People, Munich - London - New York, Prestel 2019, p. 89. 
methodology applied in this Vorkurs had an impact that pointed far beyond the pedagogical framework of the Bauhaus and was an internationally accepted methodology for decades to come, the aim of which was to enable the development of the creative (creator) individual. ${ }^{7}$

In the German-speaking countries and in Hungary, the development of the design skills and creativity of vocational students had become a fundamental feature of vocational secondary schools by the 1890s. The task of vocational education in Hungary was to produce manufacturers capable of individual work owing to their training - an idea that had its roots in Ruskin's approach focusing on medieval craftmanship. Ruskin's romantic respect for the Middle Ages provided the base for his opinion of modern craftmanship, which, however, fundamentally contradicted the industrial models of mechanization and mass production in the age of historicism. His views on raising society's level of general knowledge and on developing the taste of the masses were also connected to the ideal of medieval craftsmen. The craftsman with excellent professional skills, free to use his creativity and ideas, was guaranteed to be able to work individually, due to the certificate received from the vocational school. ${ }^{8}$ Ruskin's realization of the loosening of the traditional fabric of society happened parallel with another London-dwelling German émigré's criticism of the phenomena of mass society, popular demand, and mass production. Gottfried Semper presented his observations with regards to the object created, rather than its creator: as a result of industrial production and experimentation with materials, the forms - whether ornaments or special forms peculiar to the object - could now be produced of practically any material, as the constraints binding producers to form the object on the basis of its function and material were now eliminated after a thousand years. Precise industrial machine-made - modelling, as opposed to handmade production, likewise signaled the breaking up of the traditional order. As a child of the age of historicism, Semper, too, turned to historical experience for a solution, promoting a return to ancient motifs. One result of his standing up against excessive forms unjustifiable by function and alien to the object was visible in a renewed interest

7 Johannes Itten, How the Tremendous Influence of the Bauhaus Began, in Our Bauhaus, op. cit., p. 156.

8 Katalin Vörös, Modernizáció és nacionalizmus keresztmetszetében. Nemzetépitési törekvések a dualizmus kori középfokú iparoktatás vonatkozásában, [In the Cross-Section of Modernization and Nationalism. National Endeavors in Secondary Industrial Education in the Time of the Dual Monarchy], in Csibi Norbert-Schwarczwölder Ádám (eds.), Modernizáció és nemzetállam-épités: haza és/vagy haladás dilemmája a dualizmus kori Magyarországon, Kronosz, Pécs 2018, pp. 237259. 
in the art of original, undeteriorated, ancient cultures at the 1873 Vienna World's Fair, which had a profound effect on industrial design until the 1920s and 1930s. ${ }^{9}$

The tension between tradition and innovation continued to characterize industrial vocational education, and the issue was just as complex as the problems Ruskin and Semper raised, the solutions they proposed, and the answers they generated from 1850 to 1930. In vocational education in Hungary, the contradictory processes of reinterpreting and passing on traditions were both observable: in the establishment of location-specific institutions teaching modern specialist trade on the basis of local historical craftmanship, in the teaching of the forms of Hungarian medieval relics, and in passing on local artisan traditions connected to the educational profile of the given institution. At the same time, the spirit of innovation pervaded the entirety of vocational education: new industries such as stone grinding was set up, the newest machines and technologies were used; exhibitions were organized displaying modern tools, materials, and techniques; modern, turn-of-the-century tendencies in style were introduced in the schools, and village crafts were technologically renewed [Fig. 2].

Experimenting with an emphasis on an artistic approach, the place of designer's skills in education, and new possibilities inherent in materials also took place in the workshops of late $19^{\text {th }}$-century Hungarian vocational schools. Particular formal and technical solutions based on varying ornamentation and breaking away from the world of pattern books became prevalent. Besides conducting chemical experiments on materials, the material tester station at the Museum of Industrial Technology in Budapest also examined the architectural, interior design, ornamental, and object design applicability of these materials. The first exhibition of the Industrial Museum of Szekler Land (Székelyföldi Iparmúzeum) in Târgu Mureș (Marosvásárhely) in 1886 displayed the modelling collection of Henrik Engelsmann tinsmith's business in Budapest, introducing the public of the town -still in its early stage of civil development back then - to a technology that was capable of producing the historicizing forms and architectural sculptures of modern city architecture in a simpler and cheaper way than usual. When stone grinding was introduced in Zlatna, it not only signaled the setting up of a completely new branch of industry but also provided opportunities for using aragonite in the production of objects on an industrial scale. In Uzhhorod (Ungvár, today in the Ukraine), the vocational school of pottery operated as part of the Porcelain and Material Industry Company; here, experimenting with and perfecting the raw

9 Fabian Reifferscheidt, Wege auf der Krise - Gottfried Semper und John Ruskin, in Tobias Hoffmann (ed.), Von Arts and Crafts zum Bauhaus. Kunst und Design - eine neue Einheit!, Wienand, Köln 2019, pp. 16-25. 
materials used was an integral part of the manufacturing process. As opposed to experimenting with materials purely for the sake of the economic interests of industry development, in the period between the two world wars, modern schools utilized the previously unthought-of opportunities inherent in materials - an approach that gained a new meaning as part of creative practices and appeared as a supplement to theoretical modelling. In 1929, when the Dessau Institute grew poor due to the financial crisis, Josef Albers, teacher of the legendary preparatory course of the Bauhaus, distributed newspapers among his students and asked them to create a new form while keeping the characteristic features of the material in mind, thus encouraging them to reconsider the potentials of the material.10

Even for Gropius, who knew the tendencies of the period well, finding a balance between artistic inspiration and artisan techniques conforming to the ideals of medieval workshops was a significant challenge. The experiments conducted in the early years of the Bauhaus may seem familiar; they were similar to the ones carried out in British industrial and vocational education of the 1870s and 1890s. Both schools focused on the applicability of an artisan approach to industrial design, experimenting with the use of materials, and form-creation reminiscent of medieval revival and, at times, even inspired by the art of nonEuropean peoples. ${ }^{11}$ Emphasis on craftmanship in this early period was determined by the working methods used in Max Krehan and Gerhard Marcks's pottery workshop, which combined traditional craft with individual artistic creation and thus produced unique artefacts, rather than objects suitable for mass production. The spirit of Legros and Dalou returned 50 years later in Weimar. After the initial years, a prominent figure of De Stijl, Theo van Doesburg arrived in Weimar in February 1922 and bought along the predominance of expressionist painting, which led to the reintroduction of a hierarchical view of fine arts and applied arts. Doesburg's presence - whose architecture was characterized by the use of vertical and horizontal lines, the rejection of radical painting, and the advocacy of the communal instead of the individual - generated a serious conflict with regards to approaches to art. ${ }^{12}$ The dynamism with which Doesburg tried to turn the Bauhaus into a De Stijl school, led to the departure of Johannes Itten, famous for his legendary preparatory classes. To fill the vacant position, Gropius employed László Moholy-Nagy instead of the Dutch master. The Hungarian designer, who

\footnotetext{
10 Hannes Beckmann, Formative Years in Our Bauhaus, op. cit., p. 34; Hin Bredendieck, The Preliminary Course and Design, in Our Bauhaus, op. cit., p. 55-56.

11 Tobias Hoffmann, Die Bauhausidee - Kunst, Handwerk, Technik, Design, in Von Arts and Crafts zum Bauhaus, op. cit., p. 269.

12 Ibidem, p. 271-272.
} 
was influenced by Russian constructivism, assigned a central role to machines in the creative process, which meant that he probably saw a greater opportunity in realizing Gropius's original idea, the unity of art and technology. During the five years Moholy-Nagy spent at the Bauhaus, he had a pivotal impact on its operation. His stay coincided with the introduction of painting education initiated by Paul Klee and Wassily Kandinsky in 1927, which took place within the framework of an education system reformed for the umpteenth time. When the Bauhaus moved from Weimar to Dessau, the competition between artistic versus artisan approaches was accompanied by an increasingly prominent attitude favouring industrial production over handmade manufacturing. ${ }^{13}$ By the mid-1920s, this situation was palpable in the metalworker workshop as well. The aim of practical training was to produce objects that were worked out experimentally with artisan methods but were also suitable for mass production, that is, artefacts that were perfectly suited to both the qualities of craftmanship from an aesthetic and practical point of view, and to economical aspects of production in terms of their form. ${ }^{14}$ After the momentous 1923 Bauhaus exhibition, a need for cooperation between the teacher and students of the school and industry for the sake of production with economic benefits became inevitable. As the architecture course turned to the production of prototypes and took on a mathematical and physical approach, artistic approaches were pushed to the background and the subjects of statics and representations entered the curriculum. ${ }^{15}$ [Fig. 3].

The name Hochschule für Gestaltung [High School for Design], assumed in the previous year, indicates the intensity of the ongoing debates and continuous conceptual changes. Design, now considered to be equal to fine arts, appeared as a specific creative discipline, owing much to Hannes Meyer, head of the institute from 1928 and well-known for his radical socialist views. Meyer claimed that the main task of the institute was to educate designers who meet the demands of industrial production. Meyer's approach was influenced by his industrial vocational education prevalent all throughout Europe in the late $19^{\text {th }}$ century: he completed a further training at the industrial school of Basel and took evening classes at the arts and crafts school in Berlin. ${ }^{16}$

\footnotetext{
13 Hannes Beckmann, Formative Years, op. cit., p. 36.

${ }^{14}$ Marianne Brandt, Letter to the Younger Generation, in Our Bauhaus, op. cit., p. 50.

15 T. Lux Feininger, The Bauhaus. Evolution of an Idea, in Our Bauhaus, op. cit., pp. 105-106.

${ }^{16}$ Tobias Hoffmann, Die Bauhausidee - Kunst, Handwerk, Technik, Design, op. cit., pp. 275-277.
} 


\section{Gesamkunstwerk, architecture}

William Morris and Philipp Webb's Red House in Bexleyheath is an iconic building with a historic significance, the full impact of which could only be felt some decades after its completion in 1860. Previous architectural practice did not consider the furnishing of the house to be its task, but the architect and the textile designer's unique collaboration quickly changed the attitude of a whole generation, and a generation later it became a corner stone of the organization of the official Hungarian industrial education system and a model in force throughout the monarchy [Fig. 4]. At the same time, similar processes went on in German architecture as well. Hermann Muthesius's three-volume work, Das englische Haus, published in 1904-1905 was an important stage in its reception. Working as the technical and cultural attaché at the German embassy in London between 1896 and 1903, the German architect's work emphasized artistic unity within the English reform movements, their functionalism that rejected a search for style, and the honesty of the use of materials. ${ }^{17}$ Muthesius believed to have found the harmony of architecture and interior design in the Scottish reform movement of Charles Rennie Mackintosh, which put a greater stress on artistic solutions by interior design [Fig. 5]. Muthesius argued that it was in fact the Glasgow school, and then its follower, the Viennese school who first adapted Morris and Webb's earlier ideal - the unity of art, arts and crafts, and architecture - to fit the possibilities and needs of industrial design.

The approach of viewing architecture, interior design, and arts and crafts as a unity may also be detected in specialized courses in vocational schools. Industrial vocational schools in Hungary usually operated with two or three parallel classes and concomitant workshops. Inspired by Webb and Morris's collaboration, these classes advocated an architectural and arts and craft approach in the same institution. Besides the common education of building, wood, and metal industry, schools of pottery, stone carving, and stone grinding could also be found in Hungary, as well as education building on local industrial traditions and available raw materials: the State Woodwork School in Brașov, offering a course in furniture design, and the School of Metalwork in Gelnica [Gölnicbánya, today in Slovakia].

The architectural approach gained a pivotal role in mid-19 ${ }^{\text {th }}$-century English vocational and arts and crafts education as well, the impacts of which are clearly indicated by the Red House. In the second half of the $19^{\text {th }}$ century, the previously unknown dynamics of technological innovations posed a new challenge in

\footnotetext{
17 Tobias Hoffmann, Arts and Crafts-Rezeption, in Von Arts and Crafts to Bauhaus, op. cit., p. 139.
} 
vocational education. The training of architects in higher education was generally open to innovations and was characterized by an organic approach, which fundamentally determined the operation of vocational and arts and crafts schools and museums. All over the monarchy, these institutions were headed by architect directors with a background in architecture. Camillo Sitte, who first implemented the procedure of photographic reproduction in the curriculum of a vocational school, was director of the vocational school of Salzburg from 1875, then of the industrial vocational school in Vienna (Staatsgewerbeschule). Jenő Radisics, who reformed and energized the Museum of Applied Arts in Budapest, was a law major first, then he studied architecture at the Hungarian Royal József Nádor Technical University for four years from 1875 on. As director of the museum, both professions endowed him with useful knowledge. Lajos Pákei showed unparalleled organizational skills for museums and schools both in vocational education in Transylvania and in arts and crafts collection in Cluj. From 1872, Pákai completed his university studies and worked in architect's offices in Budapest, Vienna, and Munich. The rise of the stone carving and stone grinding school of Zlatna was owing to the appointment of architect Géza Gréb as director in 1908.

The spirit of innovation permeated education from both a technical and an artistic perspective. There were three basic channels available for adopting innovations: collaboration among teachers; constant expansion of the library by obtaining the latest patterns, materials, and equipment; and professional study trips. When selecting teachers, the main criteria were an international outlook and experience gained abroad. Inviting internationally acclaimed professionals was a practice present in vocational education from the beginning of the arts and crafts movement, but it entailed the fluctuation of the best, as the biggest names with international fame rarely spent more than three years teaching in one vocational school. There had already been examples of inviting international professionals albeit only for a short period of time - in the early stage of vocational education. During the first reform movement in England, architect Leo von Klenze and Prussian curator Gustav Waagen, among other European experts, participated in the elaboration of the concept of the School of Design, established with the aim of modernizing the education of designers. Gottfried Semper was perhaps the first internationally acclaimed expert who took part in a reform movement for a while: while an exile in London between 1852 and 1855, he was invited to give special technical classes in technical drawing, mapmaking, land survey, architectural design, mould making, molding, and chiseling. ${ }^{18}$

\footnotetext{
18 Suzan Owens, 'Straight lines are a national want', op. cit., p. 66.
} 
There were also several examples of migration within a country: Camillo Sitte, for instance, took his famous pioneering photographic reproduction classes from Salzburg to Vienna, while Lajos Pákei organized the system of an industrial museum and education in Cluj on the basis of the experience he gained in Austria and Germany. As for the secluded Zlatna, Czech and Austrian experts came to the school to teach stone carving and grinding - both introduced as new branches of industry. Studies abroad and forced emigration proved to be inspiring for the education of architecture and industrial design in the following periods as well. The world-renowned artists whose name guaranteed the acknowledgment of the school in 1919 played a fundamental role in the foundation of the Bauhaus. After the bedlam of World War I, Johannes Itten, Adolf Meyer, Wassily Kandinsky, Breuer Marcell, and Moholy-Nagy László - forced into exile - went to Weimar at Gropius's invitation.

The results of the reforms carried out at South Kensington, as well as the German theoretical and textual construction of modernizing industrial education had a well-visible impact in Budapest and Cluj in the 1890s. In the early 1880s, the Museum of Industry in Cluj appeared as a background institution to industrial vocational training in a draft prepared by Count Gyula Schweinitz, member of the local chamber. ${ }^{19}$ The latter exemplifies that European revolutions had a considerable impact on erudition and knowledgeability, though in this case it was not through forced political exile. Schweinitz, a lieutenant colonel born into a Silesian family of noble ancestry, fought at the side of Field Marshal Radetzky during the Italian revolution of 1848 . He was 59 years old when, summarizing the experience gained through his travels in Europe, he published his ideas concerning the industrial museum in Cluj, as part of his diverse activities as publicist. His conception for a museum exhibition was classified in five groups, drawing on the classification system of world fairs: he planned to display objects in the categories of raw materials, historical and modern industrial models, a technological collection, instruments, tools, and machines used for industry and agriculture, an exhibition of industrial objects and products, production samples and models from abroad, and he also planned a concomitant library of theoretical literature and a chemistry station suitable for the testing of materials. Fifteen years later, based on Schweinitz's principles, the Franz Joseph I Vocational School was opened in its first separate building, along with a vocational school of building, woodwork,

19 See Miklós Székely: Muzeul Industriei Francisc losif din Cluj, 1887-1918, in Lupescu Makó Mária, Ionuț Costea, Ovidiu Ghitta, Sipos Gábor, Rüsz-Fogarasi Enikő (eds.), Cluj - Kolozsvár - Klausenburg 700: Várostörténeti tanulmányok / Studii de Istorie Urbană, Erdélyi Múzeum-Egyesület (EME), Kolozsvár-Cluj 2018, pp. 467-479. 
and metalwork [Fig. 6]. Vocational schools in Budapest were organized with a similar approach as the ones opened in Cluj. The Museum of Industrial Technology and the connected Hungarian Royal Public Secondary Industrial School were developed with the participation of industrialists, heads of associations, members of the parliament, and ministry councilors. The institution was to be principally modelled on the Technologische Gewerbesumeum of Vienna, as well as vocational schools and industrials museums in Munich and Stuttgart. The first meeting of the committee coordinating the establishment of the institution was held in June 1882, almost simultaneously with the publication of Count Gyula Schweinitz's proposal.

\section{Vocational school students, museum audience}

The basic idea for the first world fair was to compile a global collection by exhibiting the whole spectrum of industrial production in one place. Three out of four large industrial groups listed in the programme for the Great Exhibition in London were connected to the field of industrial education: raw materials, machines and mechanical tools, and industrial products. The only exceptions were sculpture and fine arts, assigned to the fourth group. The conception of the collection, both exhibiting and applying the novelties, determined the creation of professional sample collections of vocational schools and nations, as well as the compilation of centrally organized travelling exhibitions. The first example of the latter was put together at the South Kensington Museum in 1855 for art schools in the countryside. ${ }^{20}$

The system built on central institutions became the basis of uniform national education in the British Empire and in other European nations alike. Influenced by the world exhibition, the framework of the system was elaborated by Henry Cole and Richard Redgrave at the Department of Practical Art, which intended to forward the alphabet of the education of drawing to every educational institution in the country with the help of a common framework. Three decades later, the concept of a museum-school, exhibiting objects of industry and applied art, and organizing education centrally, was realized in Hungary in almost the same form. The only important difference was that the Hungarian system consisted of not one but three industrial museums and the Museum of Applied Arts in Budapest: besides the Museum of Industrial Technology in Budapest and the Hungarian Royal Public Secondary Industrial

\footnotetext{
20 Suzan Owens, 'Straight lines are a national want', op. cit., p. 64.
} 
School, both country-wide in their scope, the Franz Joseph I Vocational School in Cluj, headed by Lajos Pákei, also played a central role, while in the highly underdeveloped Szekler Land the Industrial Museum of Szekler Land in Târgu Mureș became the central regional institution of an intensive state economic and industrial development. The Museum of Industrial Technology in Budapest, sharing a building with the Hungarian Royal Public Secondary Industrial School, was a central institution carrying out the museal and educational tasks of national industrial development. The museum consisted of a collection of tools and machines, a sample collection of finished products and raw materials, drawing classrooms, and a library of technical designs and literature. Centrally financed and under the direct supervision of the Ministry of Religion and Public Education, the task of the institution was - besides education, collection, and exhibition - to provide continuous control over rural industry, and to compile and distribute collections illustrating professional knowledge.

One of the basic features of the system of vocational schools and industrial museums working together in symbiosis was the introduction of the newest technologies, first making them available for the public in museums, then getting them to the workshops of vocational schools in the country. The industrial museum, which might be characterized as the combination of a center of innovation, an experimental laboratory, and a commercial showroom, as well as the continuous renewal of the collection, indicated the same purpose as the practice of industrial vocational schools, which offered the acquisition of the most modern knowledge to their students, through obtaining the newest, most up-to-date theoretical literature, sample books, and international periodicals. In the almost rural Transylvanian small town, Zlatna, the library of the vocational school made available the latest editions of Otto Lessing's German and Antoine Raguenet's French volumes on ornamentation in architecture, published at around 1900, as well as the newest periodicals from Budapest, Vienna, and Stuttgart, practically only after a few days of their publication.

Industrial and arts and crafts education required a complex approach and, as a result, the relationship of the students and the institutions was also complex. Besides formal education, the directors of industrial educational institutions also put a large emphasis on the students' self-improvement, the creation of study groups and student circles. As part of workshop practice, the establishment, expansion, and maintenance of the institution provided continual opportunities for practice. Likewise, working to order became an integral part of education, which introduced the students to individual work and its responsibilities, and was also an important source of income for the institutions. At present there is no 
convincing evidence as to any joint design work of teachers and students, since apart from a few examples, this phenomenon was mainly characteristic of arts and crafts education [Fig. 7]. This approach first appeared in Henry Cole's educational methods: he involved the students of the industrial school in construction works on the South Kensington building and incorporated intensive workshop activities in his experiments with new materials. ${ }^{21}$

Although the style used for arts and craft and industrial institutions was generally neo-renaissance, the study of methods of medieval craftmanship and the use of Gothic forms were still prevalent. The Gothicization of the early Arts and Crafts based on Morris's ideas was still in practice in the workshops of Hungarian industrial vocational schools when similar institutions from London through Salzburg to Târgu Mureș predominantly had Italian-style neo-renaissance buildings. The Italian orientation of the buildings of the museums of industry and applied arts, and industrial educational institutions outlived the European neorenaissance fashion of the 1870s. There were, however, quite differing attitudes in terms of the choice of values. While the Northern-Italian renaissance style of the building and interior design of the South Kensington Museum was visible in other buildings commissioned by Prince Albert, the buildings of the vocational school and museum in Cluj were examples of Italian quattrocento architecture, owing, undoubtedly, to Lajos Pákei's studies in Vienna in the 1870s, to the cult of King Matthias, pervading the whole town in the 1890s, and to a general orientation to neo-renaissance in the architecture of school buildings in Hungary.

\section{Crisis formulas, experimentation}

A scientific approach was essential to organize industrial vocational education. In the teaching of drawing, this meant practicing geometrical forms instead of stressing a fine arts approach to sketching. The practices of the German Gewerbeschule proved to be highly influential in this respect as well. During the decades of the British reform, William Dyce's Drawing Book (1842), written under the influence of his study trip in Germany, helped spread the German methodology of industrial education based on a scientific transfer of knowledge and the teaching of Mathematics. The essence of the method was to start by drawing the contours of objects and basic geometrical forms, and then to move on to more complex forms. This also denoted a break away from the fine arts approach of the Royal Academy,

${ }^{21}$ Christopher Marsden: „Une espèce de monument socialiste moderne: Architecture for the South Kensington Museum", op. cit., p. 71. 
the French model, which still exerted a strong influence on British education and which took the teaching of the portrayal of the human figure as its starting point. The use of samples and models also built on this practice of separating fines arts from applied arts, as it prioritized the rendering of understood forms over a direct copying of nature. In fact, it was this very theory that underlay the use of plaster models in education to help understand and create ornamentation, ${ }^{22}$ and which propelled Vencel Knop, teaching stone carving in Zlatna, to draw a line at modelling human figures, excluding it from the training of stone carvers. Going against the fine arts approach, Gropius's 1919 concept of the State Bauhaus in Weimar included a romanticizing medieval artisan workshop reminiscent of the Arts and Crafts: he planned to have masters (Meister) instead of professors and workshops (Werkstatt) instead of departments, headed by workmasters (Werkmeister) educated as craftsmen, teaching apprentices (Lehrling), not students. Even the term Bauhaus was coined as a modernized adaptation of the concepts of the medieval Bauhütte, the workshop of cathedral-building masters. After the initial phase this was the second step on the way to democratizing the solutions used in the Red House, which were further developed by the activities of not only the Bauhaus but of several other modern schools of art and architecture as well: "The basic principle of the whole faculty was to reject a fear from modernism, to critically choose and try out its newest results and then implement them in production." ${ }^{23}$ Although the words critically and modernism clearly signal that this idea was formulated in the period between the two world wars, the approach used represented a continuity of the ideas of industrial vocational schools back in the time of the monarchy. Identifying the source of this quote does not require much travelling in space, nor in time: these were the words of Josef Vydra (1884-1959), recalling the initial goals of the Arts and Crafts School of Bratislava, founded in 1928. ${ }^{24}$ Similarly to the majority of industrial vocational schools in Hungary, the school was founded as a private institution supported by the local Chamber of Commerce and Industry, industrialists, and entrepreneurs, and its first two teachers were L'udovít Fulla and Mikuláš Galanda.

Many of the paths leading from the Arts and Crafts to the modernity of the Bauhaus led through Hungary. Despite the number of similarities between late-19 ${ }^{\text {th }}$-century industrial vocational schools and modern art schools, there was

\footnotetext{
22 Suzan OWENS, 'Straight lines are a national want', op. cit., p. 62.

23 Lux Feininger, The Bauhaus. Evolution of an Idea, op. cit., p. 101 and Tobias Hoffmann, Arts and Crafts-Rezeption, op. cit., p. 269 and note 6.

24 N. n.: Foundation and Development of the School of Arts and Crafts, in Have no Fear of [Modernism]. Exhibition catalogue, Slovak Design Center, Bratislava2019, p. 8.
} 
one significant difference: the latter remained to be educational institutions established as a result of an individual initiative. Modern art schools of the postWorld War I period were primarily founded on the activities of the leading masters, as opposed to the industrial vocational schools of the previous decades, which were established by the municipal or the chamber and quickly became part of the national educational system. Due to considerable differences in economic and social background, industrial vocational training in the Austro-Hungarian Monarchy differs from several aspects from the Bauhaus and the other modern art schools founded in the 1920 s and 1930 s. Although late- $19^{\text {th }}$-century industrial vocational schools and the modern educational institutions similar to the one in Bratislava were established in diverse economic, political, and artistic environments; their operation, the challenges faced, and the responses to these challenges were basically the same as the reforms of the South Kensington Museum - which first reflected on the problems inherent in modern industrial and arts and crafts education - and of the Arts and Crafts movement.

The guidelines for workshop-based education and training, the implementation of technical innovations and new artistic trends into the education, an emphasis on the students' individual skills, facilitating the individual's creativity and imagination, the primary role of architecture, the adaptation of basic building principles of modern homes, strong personal relationship and cooperation between teachers and students were the bases of the educational reform that started in the 1840 s and continued for a century. The curriculum of industrial vocational schools in Hungary included the development of drawing, modelling and formcreation skills, with the help of which many of those who graduated from these institutions, made a great impact on avantgarde and modernism between the two world wars. A renowned figure of the avantgarde both in Hungary and Romania, János Mattis Teutsch, exemplifies how firm a base the vocational school of wood carving in Brașov provided for further studies in arts. The leading sculptor of modernism in Romania, Corneliu Medrea (1888-1964) began his studies at the school of stone carving in Zlatna in 1902. These two masters, albeit coming from rather different social backgrounds, experienced the crucial impact of these vocational schools on their artistic qualifications, owing to their teachers educated abroad, the methods of training building on innovations, and the libraries that made the latest publications available for them [Fig. 8]. 


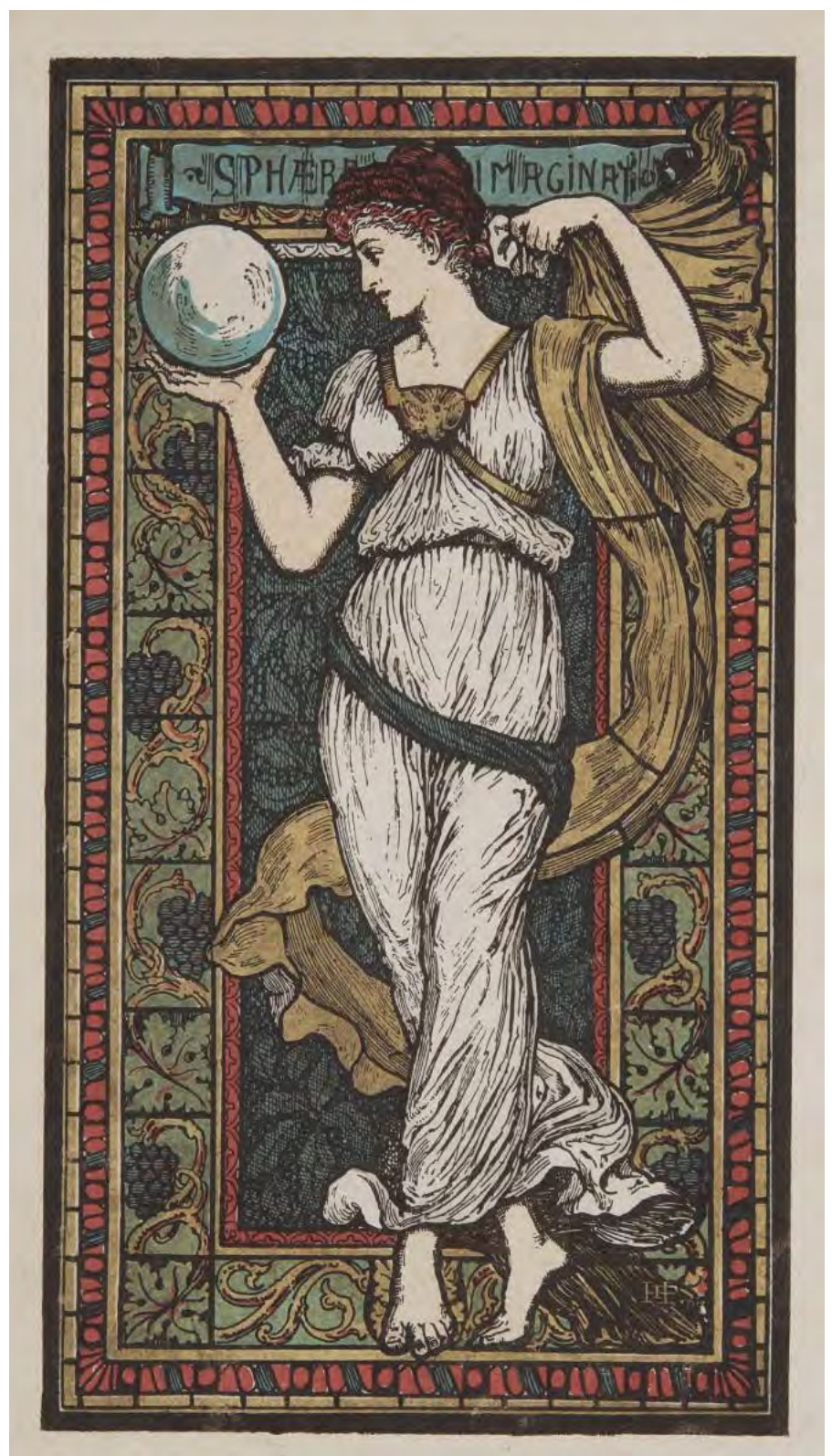

Fig 1. Walter Crane: Glass Window Design - Sphaera imaginationis. London, 1899, paper, colored, ink, $18 \times 10.7 \mathrm{~cm}$. Museum of Applied Arts, Archives.

MLT 438 Photo: Ágnes Haranghy Soltészné 


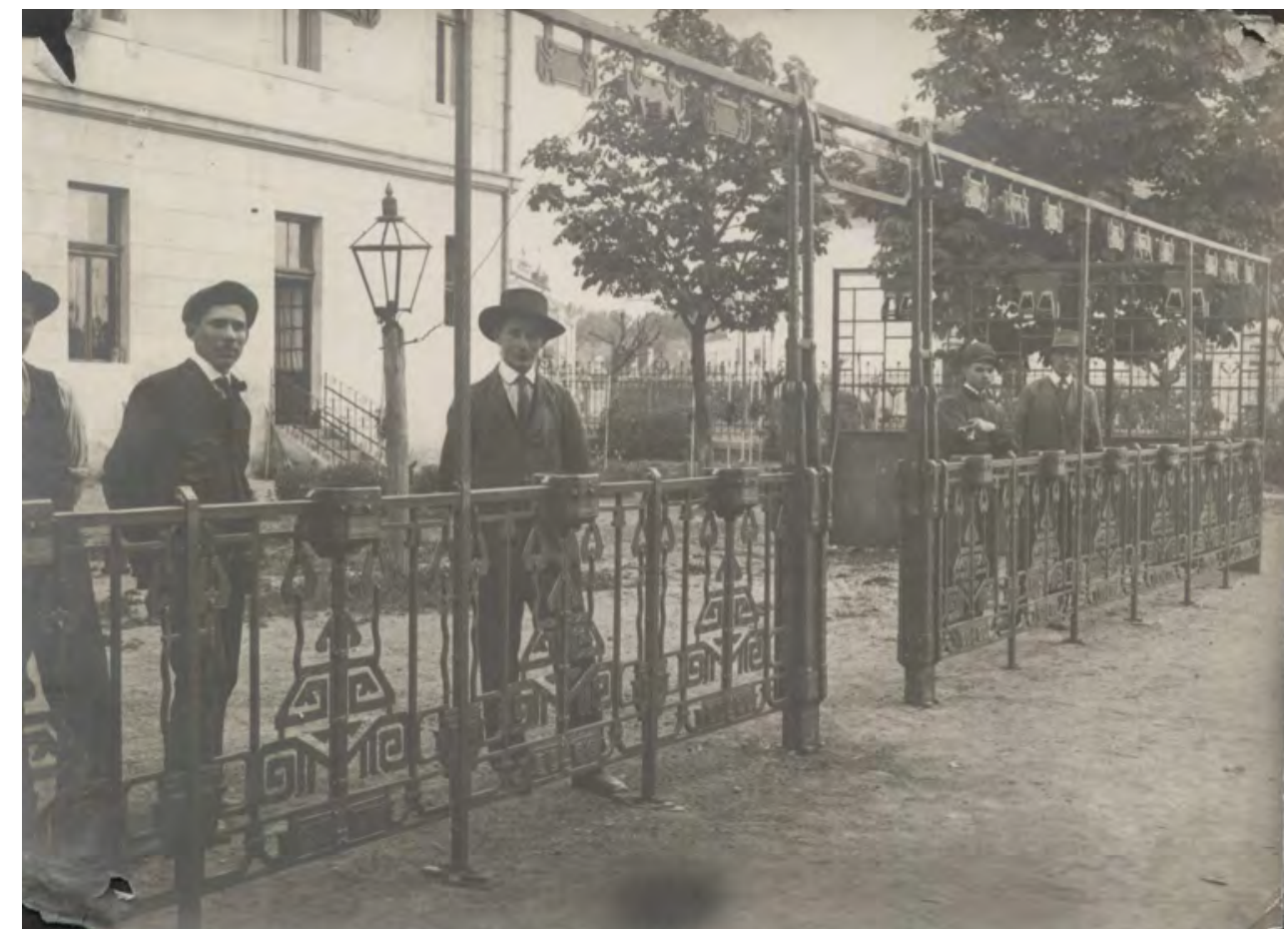

Fig 2. The terrace grid of the Royal Café in Târgu Mureş, based on the plans of the dessin teacher Mór Barát, carried out by chief foreman József Kákonyi and the students of the final class, 1915. Mureş County Museum, Photographic Collection. 3624/30 


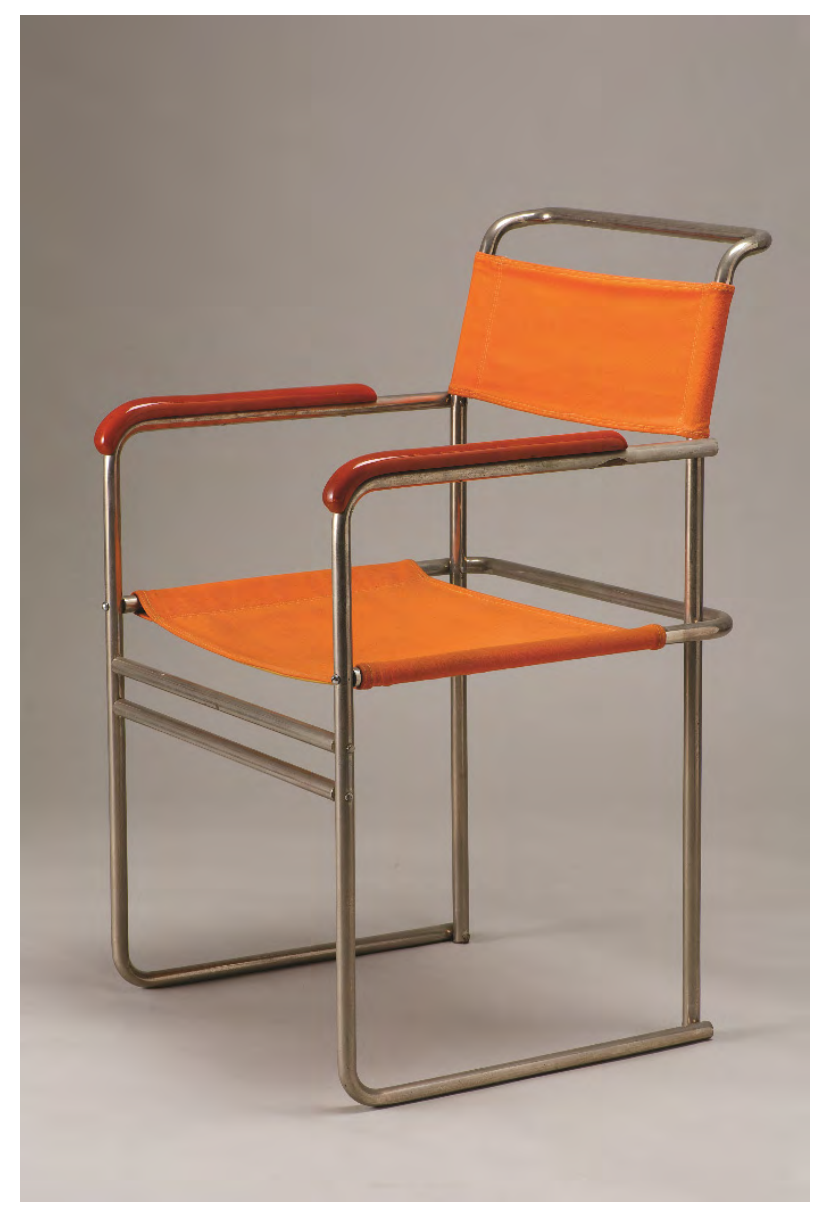

Fig 3. Breuer Marcell: tubular chair, 1930. Chrome-plated, bent steel tube, canvas, $86 \times 52 \times 45 \mathrm{~cm}$. Museum of Applied Arts, Furniture Collection.

74.118.1 Photo: Gellért Áment 


\section{MIKLÓS SZÉKELY}

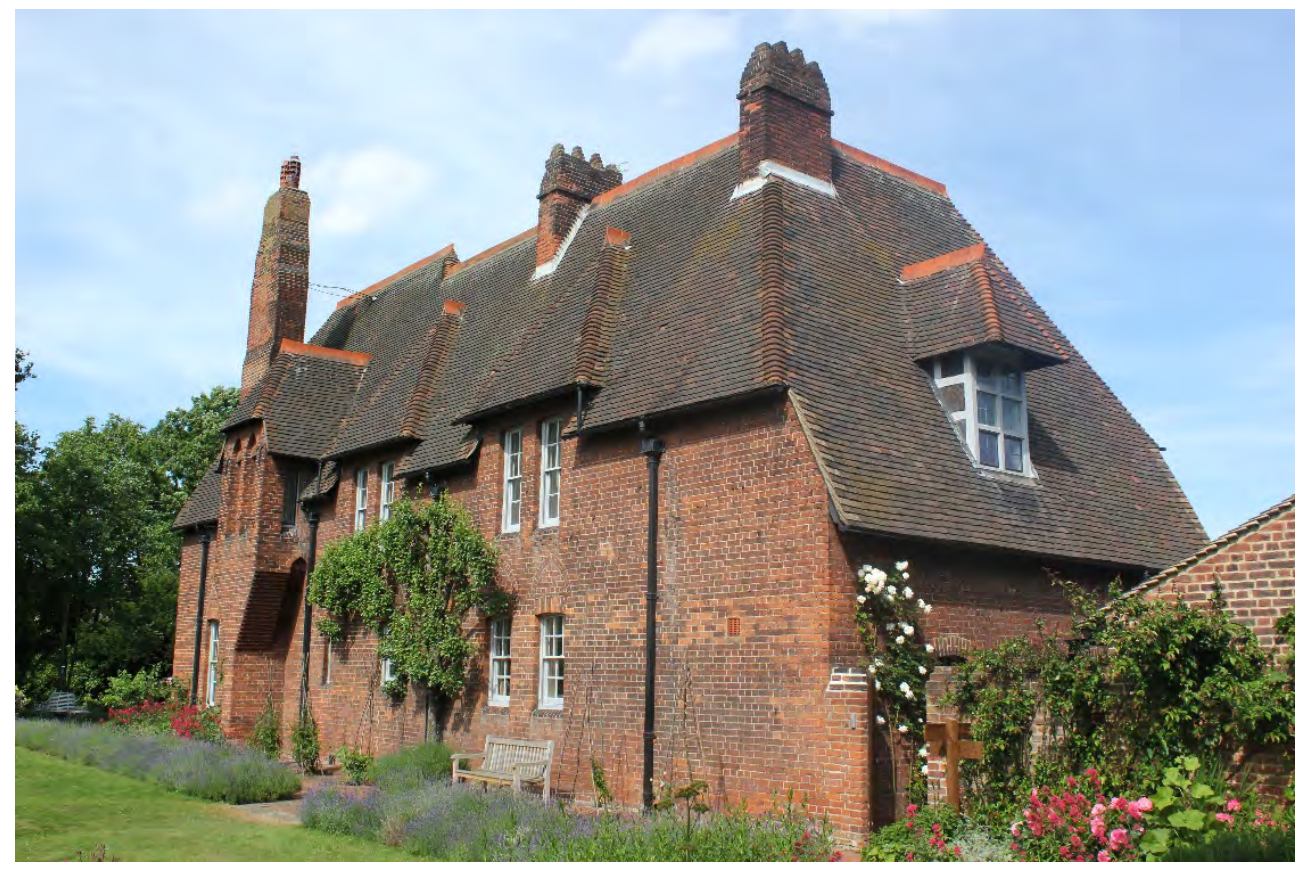

Fig 4. William Morris and Philipp Webb: Red House. Bexleyheath, 1859-1860. Author's photo, 2013. 


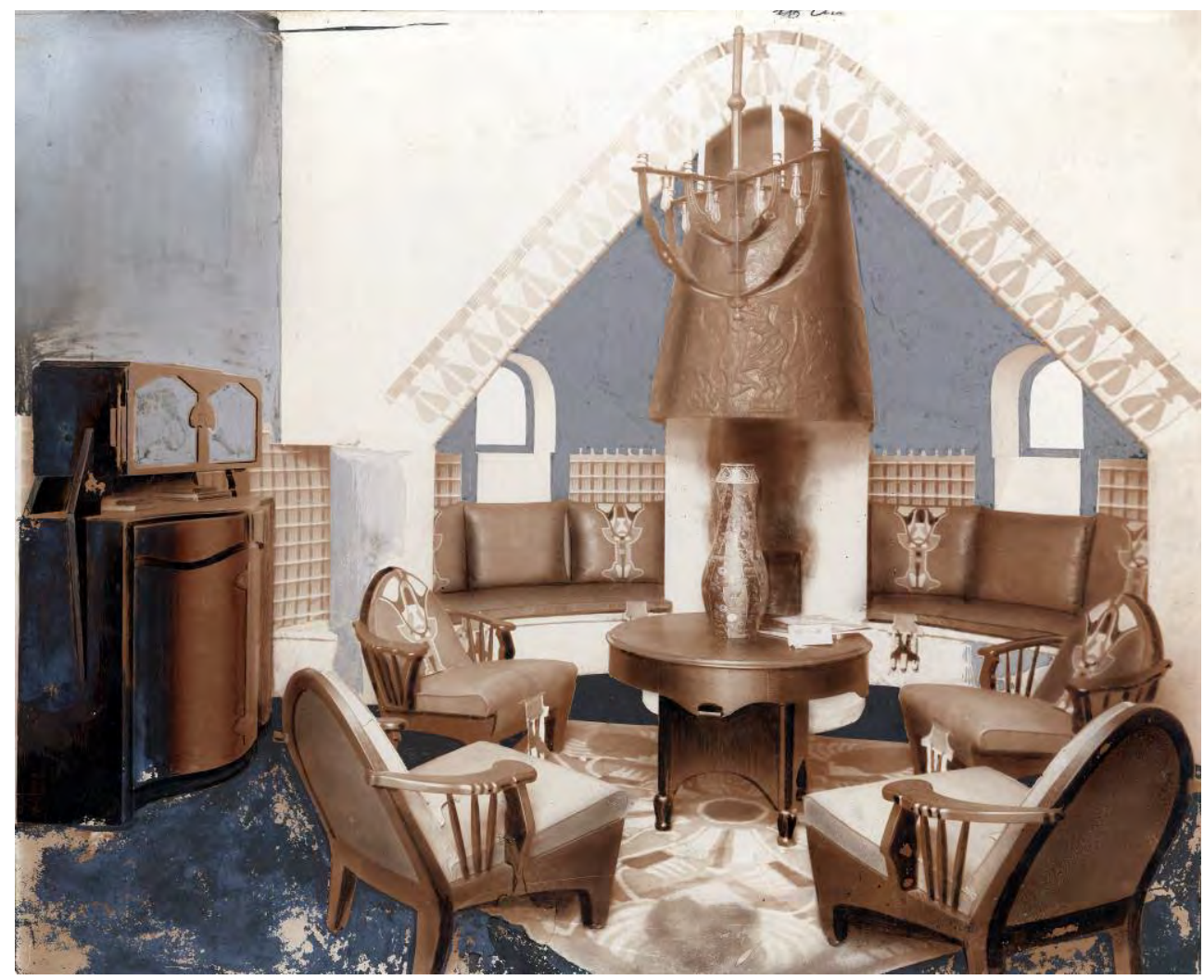

Fig 5. Exhibition photo - furnishing of a gentleman's smoking room at the Spring 1907 exhibition of the Society of Applied Arts. It was made by master carpenter József Mocsay according to the plans of Ede Wigand Toroczkai. Budapest, 1907. Black and white archive photo. Photo paper, $31 \times 25 \mathrm{~cm}$. Museum of Applied Arts, Archives, Photographic Collection, FLT 5308 


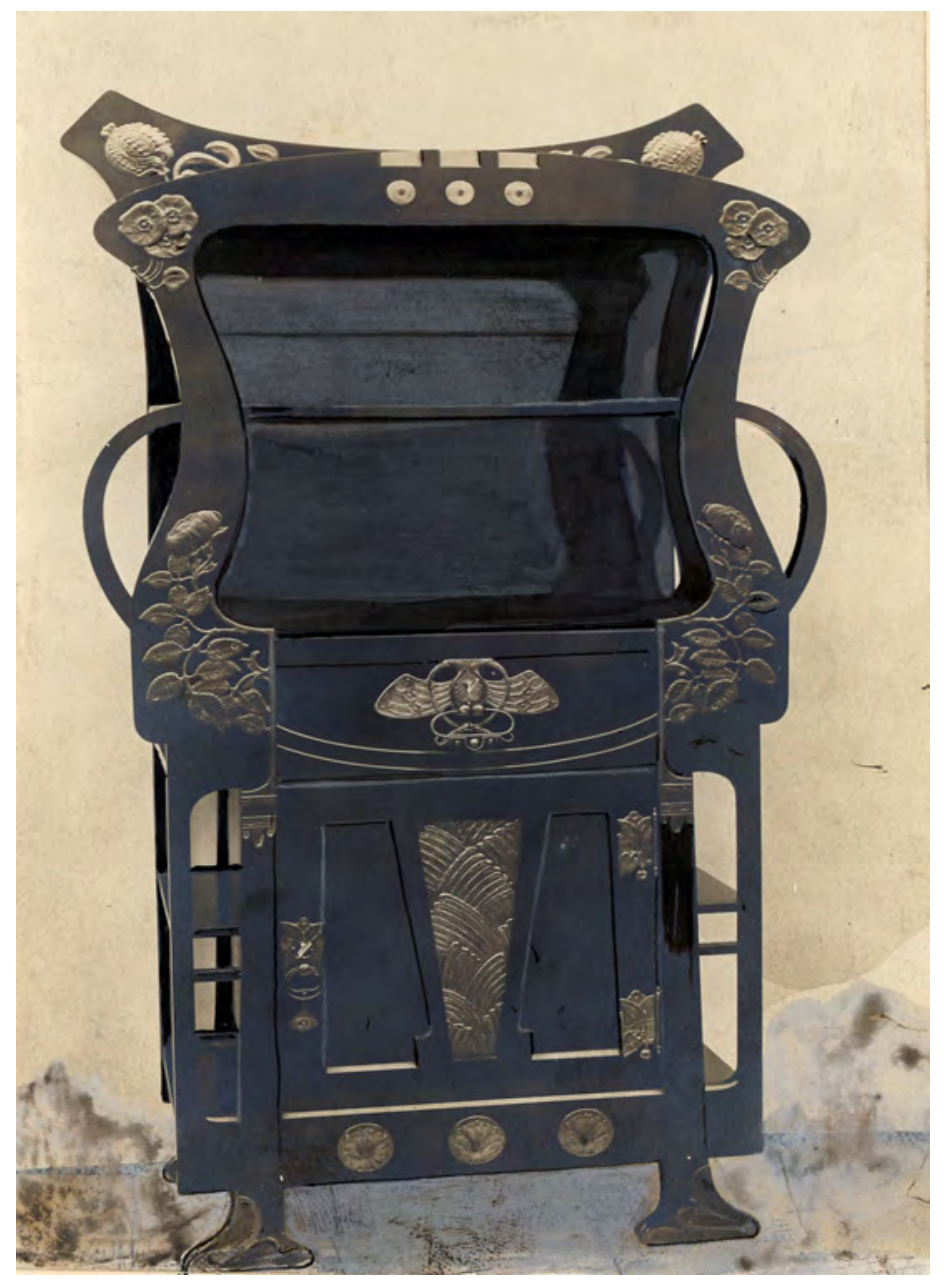

Fig 6. Salon cabinet at the 1902 Turin Decorative Arts Exhibition. It was made by J. Ferdinándy and F. Téglás according to his plans at the Vocational School of Construction, Wood and Metal Industry in Cluj. Gilded black and white archive photo; paper laminated on cardboard, $14.7 \times 8.9 \mathrm{~cm}$. Museum of Applied Arts, Archives, Photographic Collection, FLT 3580 


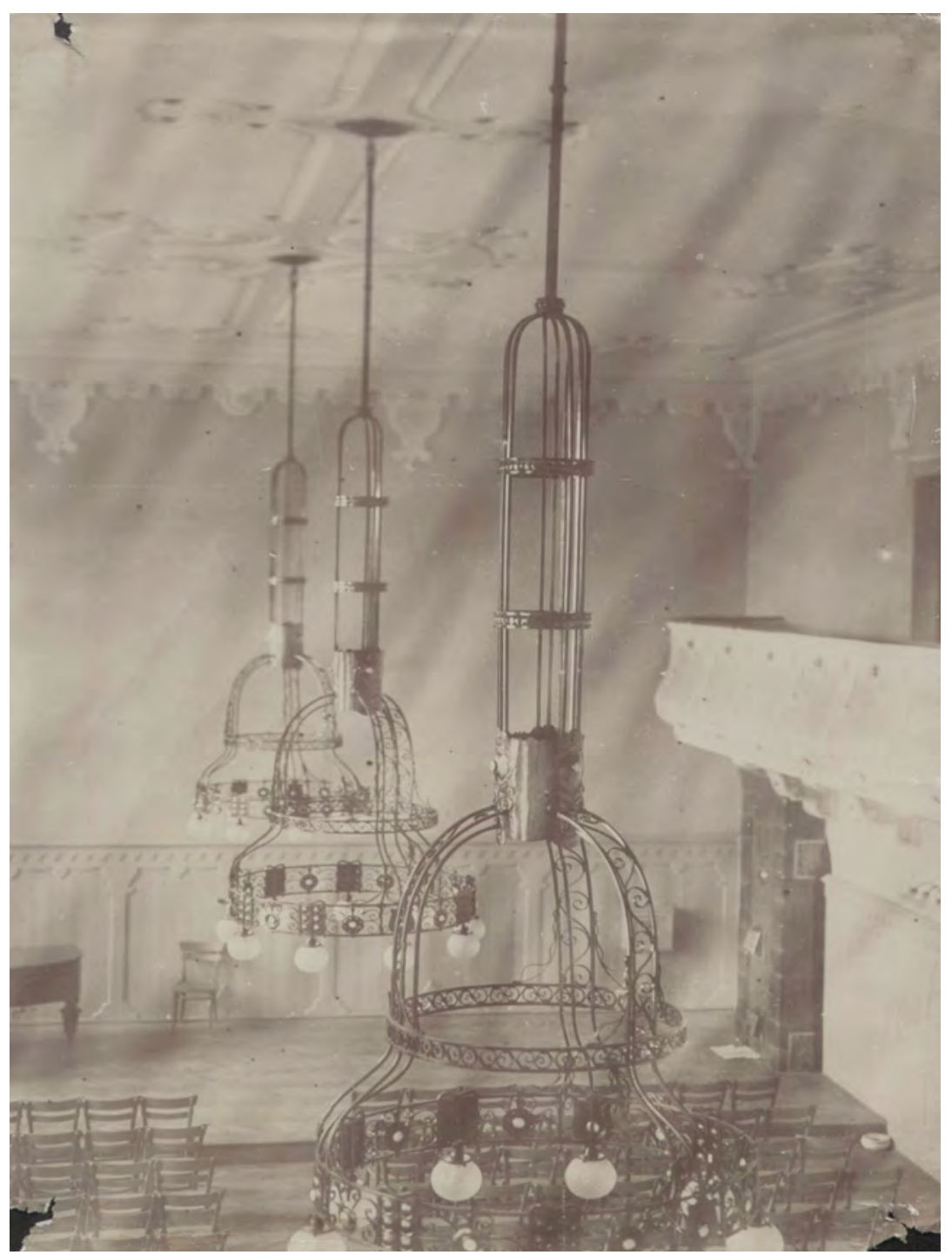

Fig 7. Chandeliers of the ceremonial hall of the Reformed College in Târgu Mureş.

Designed by teacher Győző Nagy, made by János Urszuj and Sándor Zsigmond 1910-1911. Black and white archive photo. Mureş County Museum, Photographic Collection. 3624/36 


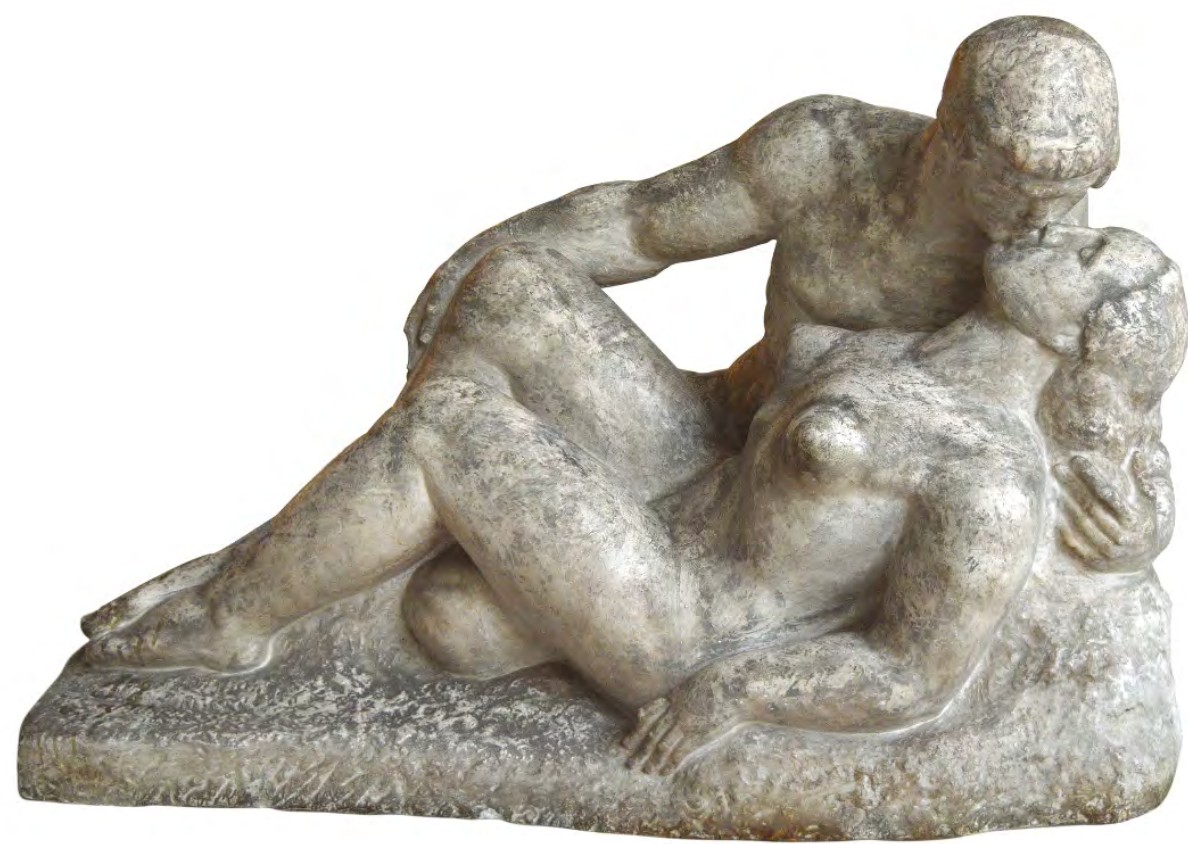

Fig 8. Corneliu Medrea: Kiss. c. 1942. ronde-bosse, plaster, $93 \times 163 \times 80 \mathrm{~cm}$. signed by the artist C. MEDREA at the base in the lower register on the right-side Gift of the artist, 1948. Bucharest Municipality Museum, Medrea Collection. Inv. Nr. 155. 